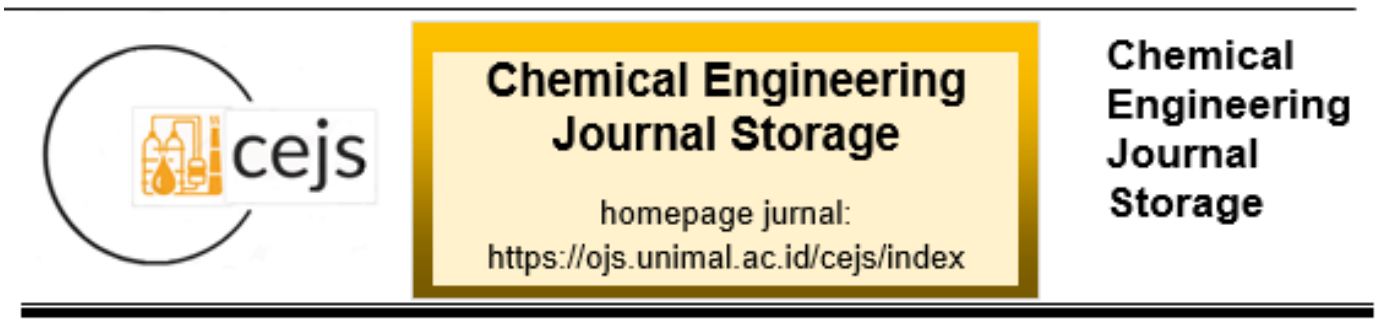

\title{
ANALISA PERFORMA KOLOM DISTILASI (105D4) DI FATTY ACID PLANT-1 PT. DOMAS AGROINTI PRIMA DENGAN SIMULASI ASPEN HYSYS
}

\author{
Jagad Wibisono, Lukman Hakim, Nasrul ZA \\ Jurusan Teknik Kimia, Fakultas Teknik, Universitas Malikussaleh \\ Kampus Utama Cot Teungku Nie Reuleut, Muara Batu, Aceh Utara - 24355 \\ Korespondensi:HP: 085296148295, e-mail: nasrulza@unimal.ac.id
}

\begin{abstract}
Abstrak
Fatty acid adalah salah satu bagian dari produk industri oleochemical. Salah satu industri hilir yang bergerak pada produksi fatty acid (asam lemak) adalah PT. Domas Agrointi Prima. Pada PT. Domas Agrointi Prima fatty acid diproduksi di fatty acid-1 plant. Untuk menghasilkan fatty acid yang sesuai spesifikasi pasar, maka perlu dilakukannya proses pemisahan dan pemurnian pada kolom distilasi/fraksinasi. Salah satu produk utama pada fatty acid-1 plant adalah fatty acid yang banyak mengandung asam oleat $\left(C_{18: 1}\right)$ yang dipisahkan dan dimurnikan pada kolom distilasi 105D4. Penelitian ini menganalisa performa kolom distilasi 105D4 pada fatty acid-1 plant PT. Domas Agrointi Prima dengan mensimulasikan proses pemisahan dan pemurnian fatty acid ke dalam aspen hysys dengan mentuning variabel suhu top column, suhu side column, suhu bottom column, pressure top dan pressure bottom yang bermaksud untuk meninjau laju alir fatty acid yang berhasil dikeluarkan pada setiap aliran, yield fatty acid aliran destilat, dan konsentrasi asam oleat pada aliran destilat untuk mendapatkan performa yang paling optimal dari kinerja kolom distilasi 105D4 dalam proses pemisahan dan pemurnian fatty acid. Hasil yang diperoleh dari penelitian ini yield produk fatty acid pada distillate stream yang paling maksimal didapatkan pada run ke 6 yaitu sebesar 99,22\%. Konsentrasi asam oleat pada produk yang keluar melalui distillate stream yang paling maksimal didapatkan pada run ke 6 yaitu sebesar 57,95\%. Kondisi operasi kolom distilasi 105D4 yang paling optimal didapatkan pada simulasi run ke 6, dimana untuk suhu top column sebesar $189,35{ }^{\circ} \mathrm{C}$, suhu side column sebesar $210,65^{\circ} \mathrm{C}$, suhu bottom column sebesar $223,69^{\circ} \mathrm{C}$, tekanan top column sebesar 9,58 mBar dan tekanan bottom column sebesar 11,87 mBar.
\end{abstract}




\section{Pendahuluan}

Industri oleochemical pada saat ini memiliki peran yang besar sebagai industri hilir dalam dunia industri yang berkembang sangat pesat, salah satunya produksi fatty acid (asam lemak) di PT. Domas Agrointi Prima. Selain untuk pemasok utama bahan pembuatan kosmetik dan sabun, industri fatty acid merupakan penyedia bahan baku utama untuk industri farmasi dan makanan. Banyak cara yang dilakukan untuk meningkatkan yield dan kemurnian fatty acid yang memang sangat dibutuhkan di proses industri, salah satu cara yang bisa dilakukan adalah melakukan analisa dan kajian proses pemisahan dan pemurnian crude fatty acid menjadi produk, sehingga dapat mengetahui proses tersebut berjalan maksimal atau tidak.

Proses tersebut raw material (dalam hal ini crude fatty acid) dipompa dari tangki penyimpanan ke dalam kolom fraksinasi untuk mengalami proses pemisahan dan pemurnian menjadi produk $\mathrm{C}_{6-8}, \mathrm{C}_{8-10}, \mathrm{C}_{1270}$, light ends, $\mathrm{C}_{18: 10 l e i c}$ dan residu. Proses ini terjadi pada section fatty acid fractionation/ distillation di fatty acid-1 plant PT. Domas Agrointi Prima. Pada section tersebut terdapat tiga kolom pemisahan yaitu kolom fraksinasi 1 (105D2), kolom fraksinasi 2 (105D3) dan kolom distilasi (105D4). Unit yang akan disimulasikan yaitu kolom distilasi yang akan memisahkan dan memurnikan produk utama yakni $\mathrm{C}_{18: 1}$ Oleic.

Destilasi adalah metode pemisahan bahan kimia berdasarkan perbedaan titik didih. Dalam penyulingan, campuran zat dididihkan sehingga menguap dan uap ini kemudian didinginkan kembali kedalam bentuk cairan. Zat yang memiliki titik didih lebih rendah akan menguap terlebih dahulu, sedangkan zat yang memiliki titik didih yang lebih tinggi akan mengembun dan akan menguap apabila telah mencapai titik didihnya (Treybal, 1981). Distilasi fraksinasi dapat dilakukan dalam pemisahan komponen yang memiliki titik didih berdekatan dan dapat digunakan untuk memisahkan bermacam-macam komponen sekaligus dalam satu kali operasi (Lister \& Renshaw, 2000).

Dalam penelitian ini dibahas variabel-variabel penting yang mempengaruhi proses pemisahan dan pemurnian di kolom distilasi (105D4). Menganalisa dan mengkaji performa kolom distilasi pada proses pemisahan dan pemurnian fatty acid 
dari crude fatty acid di fatty acid-1 plant PT. Domas Agrointi Prima dengan simulasi Aspen Hysys.

\section{Alat dan Metode}

Alat yang digunakan dalam penelitian ini adalah satu unit PC (personal computer) yang dilengkapi software engineering yaitu Aspen Hysys. Pada penelitian ini, variabel tetap yang digunakan antara lain yaitu flowrate crude fatty acid (Feed) sebesar $3809 \mathrm{~kg} / \mathrm{h}$, packed kolom distilasi yang digunakan adalah montz ring metal structured, property package yang digunakan pada Aspen Hysys adalah UNIQUAC, temperatur crude fatty acid sebesar $236^{\circ} \mathrm{C}$, tekanan crude fatty acid sebesar 31 mBar, dan komposisi crude fatty acid dapat dilihat pada Tabel 2.1.

Tabel 2.1 Komposisi feed (crude fatty acid)

\begin{tabular}{|l|c|c|}
\hline \multicolumn{1}{|c|}{ Komponen } & Komposisi & BM (Kg/Kmol) \\
\hline $\mathrm{C}_{14}$ (Myristic acid) & $0.77 \%$ & 228.36 \\
\hline $\mathrm{C}_{16}$ (Palmitic acid) & $23.27 \%$ & 256.43 \\
\hline $\mathrm{C}_{18: 0}$ (Stearic acid) & $8.99 \%$ & 284.48 \\
\hline $\mathrm{C}_{18: 1}$ (Oleic acid) & $57.82 \%$ & 282.47 \\
\hline $\mathrm{C}_{18: 2}$ (Linoleic acid) & $8.33 \%$ & 280.45 \\
\hline $\mathrm{C}_{18: 3}$ (Linolenic acid) & $0.34 \%$ & 278.43 \\
\hline $\mathrm{C}_{20}$ (Arachidic Acid) & $0.48 \%$ & 312 \\
\hline \multicolumn{1}{|c|}{ Total } & $100 \%$ & \\
\hline
\end{tabular}

(Sumber: DCS Log Sheet Data PT. Domas Agrointi Prima)

Data-data pada variabel tetap akan diinput sebagai parameter tetap pada simulasi kolom distilasi 105D4 dengan menggunakan Aspen Hysys. Adapun tahapan pada penelitian ini yaitu pemodelan kolom distilasi 105D4 pada Aspen Hysys, simulasi proses pemisahan dan pemurnian crude fatty acid pada kolom distilasi 105D4 dengan Aspen Hysys, validasi hasil pemisahan yang berhasil pada simulasi, dan evaluasi yield fatty acid paling maksimal didapatkan distillate stream, evaluasi konsentrasi oleic acid yang paling maksimal didapatkan pada distillate stream dan evaluasi kondisi optimum yang didapatkan dari hasil validasi yang berhasil.

\section{Hasil dan Pembahasan}


Penelitian ini dilakukan untuk menganalisa performa kolom distilasi (105D4) pada PT. Domas Agrointi Prima terhadap laju alir asam lemak, yield yang didapatkan, konsentrasi asam oleat yang didapat pada aliran destilat dan kondisi optimum yang didapatkan dari simulasi pemisahan dan pemurnian asam lemak dengan menggunakan Aspen Hysys.

\subsection{Evaluasi Flow Mass Fatty Acid dengan Tuning Variabel Suhu Top Column, Suhu Side Column, Suhu Bottom Column, Pressure Top dan Pressure Bottom}

Simulasi proses pemisahan dan pemurnian fatty acid menggunakan aspen hysys yaitu untuk mengetahui performa kolom distilasi (105D4) di Fatty Acid-1 Plant PT. Domas Agrointi Prima terhadap fatty acid yang dipisahkan. Oleh sebab itu, pada penelitian ini dilakukan simulasi kinerja kolom distilasi (105D4) menggunakan aspen hysys dan diberikan gangguan pada variabel Suhu Top Column, Suhu Side Column, Suhu Bottom Column, Pressure Top dan Pressure Bottom untuk mengetahui flow mass fatty acid dari keluaran light end stream, distillate stream dan bottom stream. Berikut ini adalah grafik laju alir fatty acid yang keluar di bottom stream pada simulasi kolom distilasi (105D4) pada aspen hysys yang dapat dilihat pada Gambar 3.1.

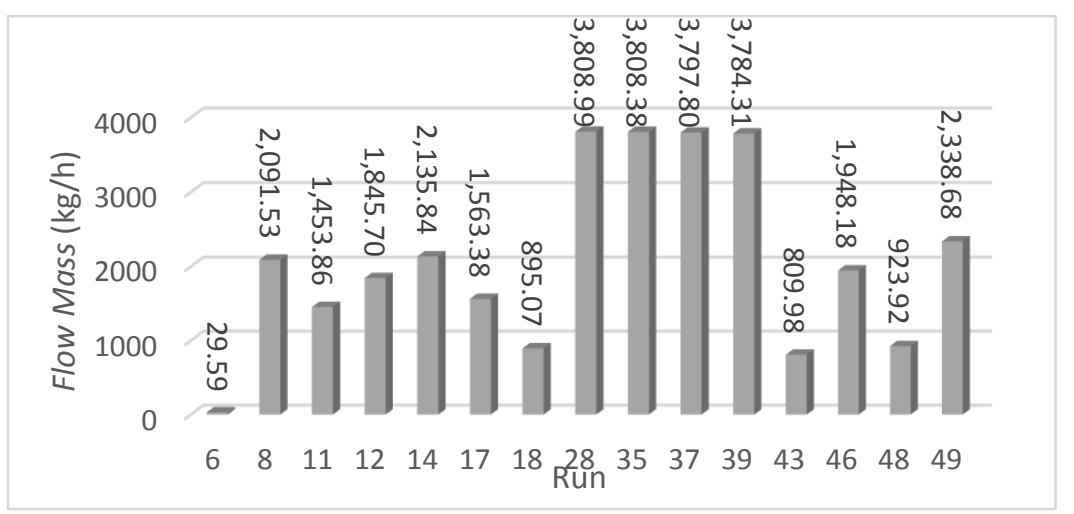

Gambar 3.1 Grafik flow mass fatty acid keluaran bottom stream

Dapat dilihat pada gambar 3.1 besarnya nilai laju alir fatty acid yang keluar melalui bottom stream pada run ke 28, 35, 37 dan 39 dikarenakan pengaturan variabel bebas menyebabkan kondisi suhu dan pengaruh tekanan pada kolom distilasi tidak dapat menguapkan komponen fatty acid ringan, yaitu asam miristat dan asam palmitat yang seharusnya dikeluarkan melalui light end stream dan komponen asam stearat dan asam oleat yang seharusnya dikeluarkan melalui 
distillate stream, selain itu hal ini disebabkan dikarenakan sifat dari produk yang saat diuapkan direboiler terkondensasi kembali sebelum mencapai aliran tengah maupun aliran atas kolom. Oleh karena itu komponen-komponen fatty acid yang seharusnya dikeluarkan pada light end stream dan distillate stream masih terikut dengan komponen berat (seperti asam linoleat, asam linolenat dan asam arakhidat) yang dikeluarkan melalui bottom stream daripada distillate stream maupun light end stream.

Penelitian ini meninjau untuk keluaran fatty acid melalui distillate stream, karena pada distillate stream tempat terpisahnya/keluarnya produk utama yaitu asam lemak yang banyak mengandung asam oleat. Adapun laju alir fatty acid yang keluar di distillate stream (side stream) pada simulasi kolom distilasi (105D4) pada aspen hysys dapat dilihat pada Gambar 3.2.

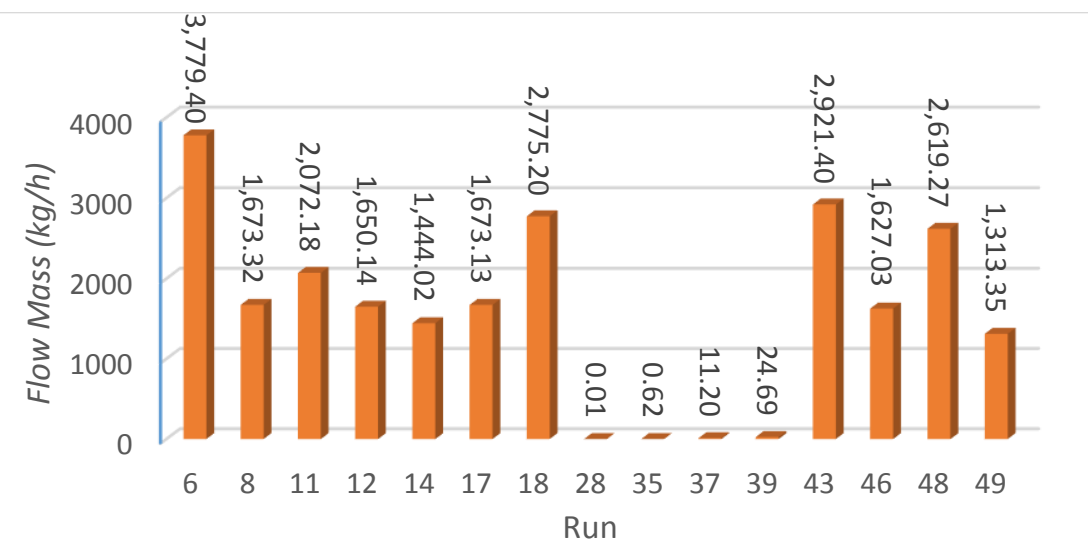

Gambar 3.2 Grafik flow mass fatty acid di keluaran distillate stream

Dapat dilihat pada Gambar 3.2 bahwa pada run ke 6, 18, 43 dan 48 didapatkan laju alir fatty acid yang dalam jumlah yang besar. Hal ini dikarenakan penyetelan kondisi suhu top column, suhu side column, suhu bottom column, pressure top column dan pressure bottom column pada run ke 6, 18, 43 dan 48 mampu memberikan kondisi operasi suhu dan tekanan yang baik pada kolom distilasi untuk menguapkan komponen fatty acid dan dikeluarkan melalui distillate stream. Selain itu setiap laju alir fatty acid yang keluar melalui distillate stream disebabkan karena pensuplaian panas dari reboiler, penyetelan kondisi tekanan dan besarnya nilai reflux pada kolom distilasi mampu memberikan kondisi operasi yang baik sehingga dapat memisahkan sebagian besar komponen-komponen fatty acid (asam stearat dan asam oleat) melalui keluaran distillate stream meskipun masih 
terikut beberapa komponen fatty acid yang seharusnya dikeluarkan melalui light end stream (asam miristat dan asam palmitat) dan bottom stream (asam linoleat, asam linolenat dan asam arakidat) pada distillate stream tersebut.

Menurut Muhammad Suharto, ddk. 2020. Kenaikan suhu bawah kolom yang disuplai oleh reboiler harus dikendalikan dengan meningkatkan nilai refluks.

Selain produk yang keluar pada distillate dan bottom stream, adapun produk yang keluar pada light end stream yang dapat dilihat pada Gambar 3.3.

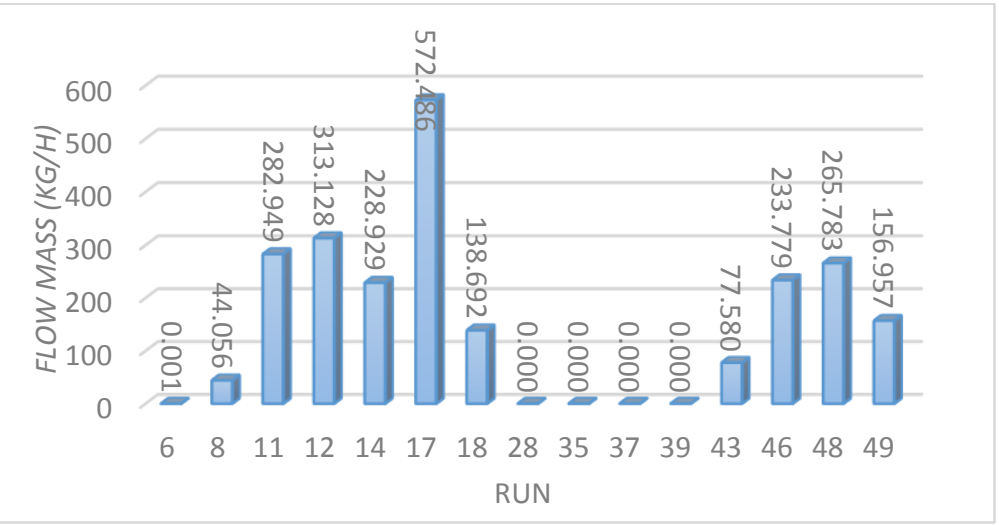

Gambar 3.3 Grafik Laju alir Fatty Acid keluaran Light End Stream

Dapat dilihat pada Gambar 3.3 keberhasilan pemisahan fraksi ringan komponen fatty acid dengan ditandai adanya laju alir fatty acid yang keluar pada light end stream ini menunjukkan penyetelan variabel bebas pada setiap run yang berhasil, sehingga mampu memberikan kondisi suhu dan tekanan operasi pada kolom distilasi yang dapat menguapkan komponen ringan yaitu asam miristat dan palmitat. Asam miristat dan asam palmitat harus dikeluarkan pada light end stream karena untuk penyesuaian komposisi produk utama (asam oleat) pada distillate stream.

Pada keadaan nyata panas pada kolom distilasi diatur/disuplai melalui reboiler, namun untuk mengatur kondisi temperatur top dan side column diatur melalui laju reflux yang masuk ke dalam kolom distilasi. Setiap panas untuk mendidihkan komponen asam lemak dipengaruhi oleh tekanan operasi.

\subsection{Evaluasi Yield Fatty Acid dan Konsentrasi Oleic Acid (Asam Oleat) pada Aliran Destilat}

Penelitian ini dilakukan untuk mengetahui untuk mengetahui yield fatty acid dan konsentrasi oleic acid (asam oleat) paling maksimal yang didapat dalam proses 
pemisahan dan pemurnian di kolom distilasi (105D4). Nilai yield yang didapat pada simulasi dapat dilihat pada Gambar 3.4.

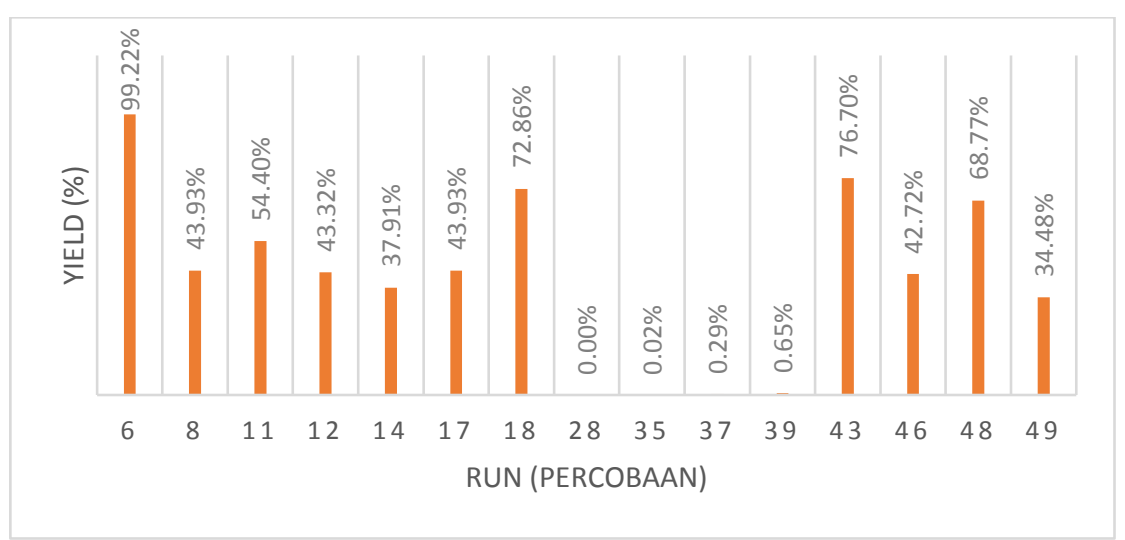

Gambar 3.4 Grafik Yield Fatty Acid Keluaran Aliran Destilat

Besarnya nilai yield pada distillate stream yang didapatkan pada run ke 6, 18, 43 dan 48 dikarenakan besarnya flow mass product fatty acid yang keluar dari aliran destilat dengan flow mass crude fatty acid yang masuk ke dalam kolom distilasi (105D4). Besarnya fatty acid yang keluar melalui distillate stream disebabkan karena penyetelan variabel bebas suhu dan tekanan yang dapat memberikan kondisi pada kolom distilasi untuk menguapkan komponen-komponen fatty acid dan dikeluarkan pada distillate stream. Sedangkan untuk yield fatty acid yang paling kecil didapatkan pada penelitian ini yaitu pada run 28, 35, 37 dan 39, hal ini dikarenakan fatty acid yang keluar melalui aliran destilat sangat kecil yang disebabkan tidak tercapainya kesetimbangan panas untuk menguapkan komponenkomponen fatty acid, sehingga pada run tersebut fatty acid paling banyak dikeluarkan melalui aliran bawah (bottom stream). Menurut Albert Sopurta dkk 2014, menyatakan seiring turunnya temperatur, komponen yang lebih volatile akan tetap pada fasa uap sedangkan komponen yang kurang volatile akan berubah menjadi cair dan ikut turun ke labu reboiler. Sehingga besarnya yield fatty acid yang keluar pada distillate stream dipengaruhi terhadap banyaknya fatty acid yang dikeluarkan atau berhasil dipisahkan pada distillate stream.

Asam oleat (oleic acid) merupakan produk utama dari komponen fatty acid yang dihasilkan pada fatty acid-1 plant PT. Domas Agrointi Prima, sehingga dalam proses pemisahan dan pemurnian fatty acid di kolom distilasi (105D4) ditinjau konsentrasi dari asam oleat pada keluaran destilat untuk menunjukkan keberhasilan 
yang maksimal dalam proses pemisahan dan pemurnian fatty acid dengan cara penyetelan variabel bebas suhu top column, suhu side column, suhu bottom column, pressure top dan pressure bottom. Adapun grafik yang menunjukkan konsentrasi asam oleat yang didapat pada aliran distilat dapat dilihat pada Gambar 3.5.

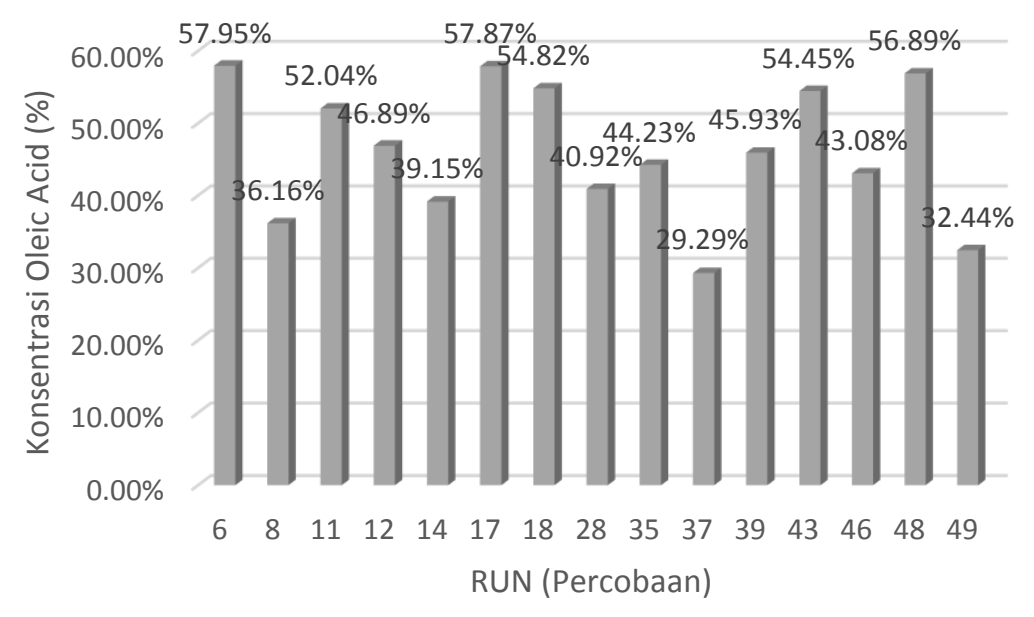

Gambar 3.5 Grafik konsentrasi oleic acid (asam oleat) pada aliran destilat

Besarnya konsentrasi asam oleat pada keluaran distillate stream pada run ke 6, 11, 17, 18, 43 dan 48 disebabkan karena keberhasilan pemisahan fatty acid pada pada kolom distilasi, dimana untuk komponen fatty acid ringan seperti asam miristat dan sebagian asam palmitat berhasil dikeluarkan pada light end stream dan untuk komponen fatty acid fraksi berat seperti sebagian asam stearat, asam linoleat, asam linolenat dan asam arakhidat dikeluarkan pada bottom stream, sehingga besarnya konsentrasi asam oleat (produk utama) sesuai dengan spesifikasi yang diinginkan yaitu minimal 50\%. Keberhasilan pemisahan dan pemurnian fatty acid ditinjau dari komponen-komponen fatty acid yang dipisahkan, komponen fatty acid fraksi ringan seperti asam miristat dan asam palmitat harus dikeluarkan pada aliran light end, untuk fraksi berat seperti asam stearat dan produk utama yaitu asam oleat dikeluarkan melalui distillate stream dan untuk komponen fraksi berat lainnya seperti asam linoleat, asam linolenat dan asam arakhidat dikeluarkan melalui bottom stream (aliran bawah). Besarnya suatu konsentrasi dipengaruhi terhadap komponen-komponen dalam suatu zat/bahan.

\subsection{Evaluasi Performa Kolom Distilasi}


Performa kolom distilasi ditinjau berdasarkan keberhasilan suatu proses pemisahan hingga tercapainya produk yang diinginkan. Pada penelitian ini dilakukan juga peninjauan performa terbaik (paling optimal) dari percobaan yang telah dilakukan, peninjauan permforma terbaik dalam proses pemisahan dalam penelitian ini didasarkan atas laju alir produk dan konsentrasi asam oleat yang paling besar/maksimal (sesuai spesifikasi produk minimal 50\%) pada keluaran distillate stream. Pada penelitian ini didapatkan percobaan yang menghasilkan produk asam oleat yang sesuai spesifikasi produk yaitu pada run ke 6, 11, 17, 18, 43 dan 48, maka yang ditinjau dalam evaluasi performa kolom distilasi hanya pada run tersebut.

Adapun data perbandingan hasil produk yang telah didapatkan pada percobaan $6,11,17,18,43$ dan 48 dapat dilihat pada Tabel 4.6.

Tabel 4.6 Perbandingan produk yang didapatkan yang sesuai dengan spesifikasi produk asam oleat di Fatty Acid Plant PT. Domas Agrointi Prima

\begin{tabular}{|c|c|l|c|c|c|c|c|c|}
\hline \multirow{2}{*}{ Run } & \multirow{2}{*}{ Yield } & \multicolumn{7}{|c|}{ Cpesifikasi } \\
\cline { 3 - 9 } & & $\mathbf{C 1 4}$ & $\mathbf{C 1 6}$ & $\mathbf{C 1 8 : 0}$ & $\mathbf{C 1 8 : 1}$ & $\mathbf{C 1 8 : 2}$ & $\mathbf{C 1 8 : 3}$ & C20 \\
\cline { 3 - 9 } & $\mathbf{1 . 0} \mathbf{m a x}$ & $\mathbf{1 5 - 3 2}$ & $\mathbf{6 - 1 2}$ & $\mathbf{5 0} \mathbf{m i n}$ & - & $\mathbf{0 . 9} \mathbf{m a x}$ & - \\
\hline $\mathbf{6}$ & $99,22 \%$ & $0,78 \%$ & $23,45 \%$ & $8,97 \%$ & $57,95 \%$ & $8,38 \%$ & $0,34 \%$ & $0,13 \%$ \\
\hline $\mathbf{1 1}$ & $54,40 \%$ & $0,14 \%$ & $30,45 \%$ & $5,97 \%$ & $52,04 \%$ & $11,06 \%$ & $0,33 \%$ & $0,00 \%$ \\
\hline $\mathbf{1 7}$ & $43,93 \%$ & $0,05 \%$ & $22,48 \%$ & $6,62 \%$ & $57,87 \%$ & $12,60 \%$ & $0,37 \%$ & $0,00 \%$ \\
\hline $\mathbf{1 8}$ & $72,86 \%$ & $0,24 \%$ & $27,77 \%$ & $7,01 \%$ & $54,82 \%$ & $9,82 \%$ & $0,34 \%$ & $0,00 \%$ \\
\hline $\mathbf{4 3}$ & $76,70 \%$ & $0,39 \%$ & $28,22 \%$ & $7,07 \%$ & $54,45 \%$ & $9,53 \%$ & $0,34 \%$ & $0,00 \%$ \\
\hline $\mathbf{4 8}$ & $68,77 \%$ & $0,12 \%$ & $25,10 \%$ & $7,30 \%$ & $56,89 \%$ & $10,24 \%$ & $0,35 \%$ & $0,00 \%$ \\
\hline
\end{tabular}

Dari Tabel 4.6 dapat dilihat bahwa nilai yield dan konsentrasi asam oleat paling maksimal terdapat pada run ke 6 yaitu untuk yield sebesar 99,22\% dan konsentrasi sebesar 57,95\%. Sehingga berdasarkan hasil simulasi aspen hysys terhadap keberhasilan pemisahan dan pemurnian fatty acid di kolom distilasi 105D4 diketahui kondisi yang paling optimal dari keseluruhan run (percobaan) didapatkan pada run ke 6, yaitu dengan kondisi variabel suhu top column sebesar $189,35^{\circ} \mathrm{C}$, suhu side column sebesar $210,65{ }^{\circ} \mathrm{C}$, suhu bottom column sebesar $223,69{ }^{\circ} \mathrm{C}$, tekanan top column sebesar 9,58 mBar dan tekanan bottom column sebesar 11,87 mBar. Hal ini dikarenakan pada proses simulasi pada run ke 6 didapatkan produk fatty acid pada keluaran distillate stream dengan yield dan konsentrasi asam oleat 
yang paling maksimal diantara hasil simulasi pada run lainnya. Selain itu, komposisi produk yang berhasil dipisahkan pada simulasi run ke 6 sesuai dengan spesifikasi produk dari Fatty Acid Plant PT. Domas Agrointi Prima yang dapat dilihat pada Tabel 4.6.

\section{Kesimpulan}

Berdasarkan hasil penelitian analisa performa kolom distilasi 105D4 pada fatty acid-1 plant PT. Domas Agrointi Prima dengan simulasi menggunakan aspen hysys, maka dapat diambil kesimpulan:

1. Yield produk fatty acid pada distillate stream yang paling maksimal didapatkan pada run ke 6 yaitu sebesar 99,22\%.

2. Besarnya nilai yield pada run ke $6,11,17,18,43$ dan 48 disebabkan atas produk yang dikeluarkan pada distillate stream terhadap crude fatty acid yang masuk.

3. Konsentrasi asam oleat pada produk yang keluar melalui distillate stream didapatkan pada run ke 6 yaitu sebesar $57,95 \%$.

4. Konsentrasi produk utama (komponen utama) pada distillate stream dipengaruhi oleh komponen fatty acid lainnya yang seharusnya dikeluarkan pada light end stream ataupun bottom stream.

5. Kondisi operasi kolom distilasi 105D4 yang paling optimal didapatkan pada simulasi run ke 6, dimana untuk suhu top column sebesar $189,35^{\circ} \mathrm{C}$, suhu side column sebesar $210,65^{\circ} \mathrm{C}$, suhu bottom column sebesar $223,69^{\circ} \mathrm{C}$, tekanan top column sebesar 9,58 mBar dan tekanan bottom column sebesar 11,87 mBar.

\section{Daftar Pustaka}

Aspen. (2012). Aspen HYSYS. Aspen Technology, USA, 2012.

Carlson, E. (1996). Don't Gamble With Physical Properties For Simulation. Chemical Engineering Progress. October, 35-46.

Dahm, K. (2002). Use of process simulation and McCabe-Thiele modeling in teaching distillation. ASEE Annual Conference Proceedings, 9311-9318. https://doi.org/10.18260/1-2--10416

Devi, S., Sonya, A., Kimia, J. T., Malang, P. N., Soekarno, J., No, H., 
Menggunakan, T., \& Chemcad, S. (2020). Pengaruh Laju Alir Umpan Distilasi Pada Pemurnian Triacetin Menggunakan Simulasi Chemcad 7.1.5. Distilat: Jurnal Teknologi Separasi, 6(2), 137-142. https://doi.org/10.33795/distilat.v6i2.115

Diana, P., Eki, K., Suryandari, S., Kimia, J. T., Malang, P. N., Soekarno, J., \& No, H. (2020). Studi pengaruh suhu. 6(9), 123-129.

Emmaputri, F. S., Nurjanah, S., Mardawati, E., Kramadibrata, M. A. M., Muhaemin, M., Daradjat, W., Handarto, H., \& Herwanto, T. (2019). Kajian Proses Destilasi Fraksinasi Biodiesel Kemiri Sunan (Reutealis trisperma). Jurnal Teknotan, 12(2), 29.

Flagella, Z., Rotunno, T., Tarantino, E., Di Caterina, R., \& De Caro, A. (2002). Changes in seed yield and oil fatty acid composition of high oleic sunflower (Helianthus annuus L.) hybrids in relation to the sowing date and the water regime. European Journal of Agronomy, 17(3), 221-230. https://doi.org/10.1016/S1161-0301(02)00012-6

Geankolis, C.J. (1993). Transport Processes and Unit Operations, $3^{\text {rd }}$ Edition. Englewood Cliffs: P T R Prentice-Hall Inc

Gilbert, J,C. and Martin, S,F. (2010). Experimental Organic Chemistry: A Miniscale and Microscale Approach, $5^{\text {th }}$ edition. USA: Cengage Learning.

Giwa A. (2012). Steady-State Modeling of n-Butyl Acetate Transesterification Process Using Aspen PLUS: Conventional versus Integrated. ARPN Journal of Engineering and Applied Sciences, 7(12), 1555-1564.

Giwa, A. and Karacan, S. 2012c. Simulation and optimization of ethyl acetate reactive packed distillation process using Aspen HYSYS. The Online Journal of Science and Technology, 2(2), 57-63.

Giwa, A., Bello, A., \& Giwa, S. O. (2014). Performance Analyses of Fatty Acids in Reactive Distillation Process for Biodiesel Production. International Journal of Scientific \& Engineering Research, 5(12), 529-540.

Glasser, F., Doreau, M., Ferlay, A., \& Chilliard, Y. (2007). Technical note: Estimation of milk fatty acid yield from milk fat data. Journal of Dairy Science, 90(5), 2302-2304. https://doi.org/10.3168/jds.2006-870

Hamid, A. K. (2007). HYSYS: An introduction to chemical engineering simulation. Simulation, 4-5. http://eprints.utm.my/3030/ 
Hani, U., \& Astuti, D. W. (n.d.). Evaluasi Kinerja Kolom Fraksinasi Crude Distillation Unit (CDU) pada Bebagai Operasi Over Kapasitas dengan Simulasi Hysys.

Karacan, S., \& Karacan, F. (2014). Simulation of reactive distillation column for biodiesel production at optimum conditions. Chemical Engineering Transactions, 39(Special Issue), 1705-1710. https://doi.org/10.3303/CET1439285

Kimia, J. T., Malang, P. N., Soekarno, J., \& No, H. (2020). Simulasi Pengaruh Performa Reaktor Esterifikasi Metil Asetat Terhadap Nilai Fouling Factor Preheater Kolom Distilasi. Distilat: Jurnal Teknologi Separasi, 6(2), 249-253. https://doi.org/10.33795/distilat.v6i2.81

Lister, T. and Renshaw, J. (2000). Understanding Chemistry for Advanced Level, $3^{\text {rd }}$ edition. Cheltenham: Nelson Thomes.

Moehady, B. I., Putri, A., \& Mayasari, E. (n.d.). MENINGKATKAN KONSENTRASI ETHYLENE DICHLORIDE ( EDC ) UMPAN FURNACE ( STUDI DI PT ASAHIMAS CHEMICAL ). 8-14.

Mondal, S. K., Uddin, M. R., Majumder, S., \& Pokhrel, J. (2015). HYSYS Simulation of Chemical Process Equipments. Chemical Engineering and Processing, SEPTEMBER 2015, 1-7.

Muhammad Yusuf Ritonga. (2013). Hubungan Ketergantungan Proses Antara Proses Splitting Dan Distilasi Pada Industri Oleokimia. Jurnal Teknik Kimia USU, 2(2), 21-24. https://doi.org/10.32734/jtk.v2i2.1433

Ramsden, E.N. (2012). Key Science Chemistry, $3^{\text {rd }}$ edition. United Kingdom: Nelson Thomes.

Ratih, P., Ali, A., \& Susianto, -. (2015). Pemodelan Dan Simulasi Distilasi Batch Broth Fermentasi Pada Tray Column Dengan Serabut Wool. Jurnal Teknik Kimia, 9(2), 44-49.

Reka, J., \& Volume, B. (2016). OPTIMASI PROSES DESTILASI UAP ESSENTIAL OIL Zuhdi Ma'sum dan Wahyu Diah Proborini PS. Teknik Kimia, Fak. Teknik. Universitas Tribhuwana Tunggadewi. 1(2), 105-109.

Rich, T. P. (2007). Chemical Process Simulation and the AspenTech HYSYS Software by. Simulation.

Soputra, A., Siregar, P. I., \& Ekawati, E. (2015). Perancangan Sistem Simulasi 
HYSYS \& Integrasi dengan Programmable Logic Controller-Human Machine Interface : Studi Kasus pada Plant Kolom Distilasi Etanol-Air. Jurnal Otomasi Kontrol Dan Instrumentasi, 6(1), 1. https://doi.org/10.5614/joki.2014.6.1.1

Teknik, F., Studi, P., Industri, T., \& Bawang, U. T. (n.d.). OPTIMALISASI KINERJA KOLOM FRAKSINASI DI PT X Suharto, Agung Dwi Hasdianto.

Teknologi, I., \& Malang, N. (2015). Teknik kimia fakultas teknologi industri institut teknologi nasional malang 2015.

Teknologi, J., Pertanian, H., Pertanian, F., \& Syiah, U. (2007). Efek Pemanasan terhadap Rendemen Lemak pada Proses Pengepresan Biji Kakao. Jurnal Rekayasa Kimia \& Lingkungan, 6(2), 50-54.

Treybal, R.E. 1981. Mass Transfer Operations, $3^{\text {rd }}$ Edition. Rhode Island: McGrawHill Book Co.

Wang, Y., Zhang, Y., Wang, J., \& Meng, L. (2009). Effects of volatile fatty acid concentrations on methane yield and methanogenic bacteria. Biomass and Bioenergy, 33(5), 848-853. https://doi.org/10.1016/j.biombioe.2009.01.007 